\title{
A structural equation model to analyse the antecedents to students' web-based problem-solving performance
}

\author{
Gwo-Jen Hwang \\ National Taiwan University of Science and Technology, Taipei, Taiwan \\ Fan-Ray Kuo \\ National Cheng-Kung University, Tainan, Taiwan
}

\begin{abstract}
Web-based problem-solving, a compound ability of critical thinking, creative thinking, reasoning thinking and information-searching abilities, has been recognised as an important competence for elementary school students. Some researchers have reported the possible correlations between problem-solving competence and information searching ability; however, few studies have proposed what factors might affect students' web-based problem-solving performance. In this study, a five-phase web-based learning approach is proposed; moreover, a web-based problem-solving model was developed to investigate the factors that might affect students' web-based problem-solving performance. To evaluate the effectiveness of the proposed approach, an experiment was conducted by engaging 201 fifth- and sixth-graders from three elementary schools in a series of web-based problem-solving activities. Structural equation modelling was employed to analyse the antecedents affecting the students' web-based problem-solving performance. From the analysis results, it was found that task-technology fit could be the major factor affecting the students' intention to learn on the Web, as it highly affected their web-based problem-solving performance.
\end{abstract}

\section{Introduction}

With the rapid spread and advancement of information technology, the 21st century has become a knowledge economy era. People who are able to obtain knowledge will be more competitive in society. Thus, schooling not only plays the important role of imparting knowledge to students, but also cultivates the students' abilities of collecting data, extracting information from the data, and applying the collected information to deal with upcoming challenges and problems (Ates \& Cataloglu, 2007; Dogru, 2008; Francis, 2008; Hwang, Chiu, \& Chen, 2015; Pimta, Tayruakham, \& Nuangchalerm, 2009; Zakaria \& Yusoff, 2009). For this reason, the education policy in Taiwan puts emphasis on ten fundamental skills incorporated in student-centred learning activities and real-life experiences (Hwang, Hung, Chen, \& Liu, 2014). Among these skills, high-order thinking and problem solving are viewed as important abilities in the current education environment. Studies have revealed several factors affecting students' problem-solving abilities, such as intelligence, learning materials, learning methods, problem-solving instructional strategies, and parents' socio-economic background (Oloruntegbe, Ikpe, \& Kukuru, 2010; Zheng, 2007). Among these, learning methods and problem-solving instructional strategies are considered as the key factors; as such, research into these issues has mushroomed (Lo, 2009; Tsai \& Shen, 2009). Researchers have found a correlation among information-searching skills, cognitive structure and problem-solving abilities (Eisenberg \& Berkowitz, 1990). For instance, Kuo and Hwang (2014) found that web-based problem-solving ability is a process of high-order thinking, consisting of critical thinking, creative thinking, reasoning thinking and information searching on the Internet. Raes, Schellens, Wever, and Vanderthoven (2012) indicated that when learners are solving a problem using web resources, their web searching performances are significantly related to their critical thinking, creative thinking and inferential thinking abilities; moreover, such an ability to search for and use web resources is highly related to their problem-solving performance. Bilal $(2001,2002)$ further indicated that the lack of effective information searching strategies and high-order thinking abilities could influence students' performance in solving problems on the Internet. Recently, Kantra (2014) published an article relating to web searching tips in Time emphasising that searching for information is an essential skill nowadays. However, most previous research concerning students' information searching and problem-solving abilities has focused on the difficulties encountered by students in web searching, with few of them concentrating on the investigation of the factors influencing students' web-based problem-solving performance. 
Nowadays, with the rapid development of computer and Internet technologies, knowledge can be derived from diverse sources accessible via the Internet. To cultivate students' web-based information seeking ability via the Internet is essential from the viewpoint of multiple intelligences (Gardner, 1993), indicating that people are encouraged to receive diverse information from a wide range of sources, which will allow them to identify and resolve the authentic problems they face. Web-based information seeking can be viewed as part of digital literacy, which facilitates the ability to use digital technology, communication tools or networks to locate, critique, summarise, evaluate, and create information (Gui \& Argentin, 2011; Kuo, Chen, \& Hwang, 2014). Thus, applying the advantages of the Internet to instructional design, especially in problem-solving instruction, is likely to improve students' problem-solving ability. However, as the information available via the Internet is both abundant and complex, students may easily get lost if they are not equipped with the necessary filtering, analysing and judging abilities (Elmer-Dewitt, 1995). Thus, it is worth studying how to integrate effective instructional approaches into web-based learning environments to improve students' web-based problem-solving performance. Besides, a review of previous research in learning technology shows that there is a lack of studies examining the crucial factors that determine students’ learning performance.

Consequently, this study attempts to develop a web-based learning environment which incorporates the problem-solving theory for assessing students' problem-solving performance. Moreover, a model to address the factors that affect students' web-based problem-solving performance is proposed and validated.

\section{Literature review}

Effectively applying problem-solving approaches can immerse students in active and investigative learning (Sellwood, 1989). Through participation in a series of practical problem-solving activities that may involve designing, modelling, and testing of technological solutions, it is assumed that the learner will acquire both technical knowledge and higher-order cognitive skills. Many researchers have proposed different approaches and procedures for solving problems. For instance, Polya (1957) proposed a heuristic process for solving problems in mathematics that provides a mental guideline for action. The steps in Polya's heuristic consist of (1) understanding the problem, (2) devising a plan, (3) carrying out the plan, and (4) looking back and checking the results and evaluating the solution. Extending Polya's approach, Bransford and Stein (1984) developed the IDEAL model of problem-solving: (1) identifying problems and opportunities, (2) defining goals, (3) exploring possible strategies, (4) anticipating outcomes and acting, and (5) looking back and learning.

Owing to the advancement and popularity of computer and network technologies, many studies investigating the factors influencing students' problem-solving performance and learning achievement have been conducted in web-based learning environments in recent years (Chang, Barufald, Lin, \& Chen, 2007; Crippen \& Eari, 2007; Gerdprasert, Pruksacheva, Panijpan, \& Ruenwongsa, 2010; Jang, 2009; Narciss, Proske, \& Koerndle, 2007). For example, Wang and Wu (2008) applied a social cognitive perspective to explore the role of self-efficacy, student feedback behaviour, and the use of learning strategies in problem solving and performance in a web-based learning environment. The results of their study indicate that high self-efficacy students apply more high-level learning strategies, such as elaborative strategies and critical thinking. The students in their study who provided elaborated feedback also had higher self-efficacy than those who did not. Kuo and Hwang (2014) indicated that the integration of appropriate problem-solving tasks into web-based learning environments could increase both high graders' problem-solving performance and intention to search for information on the Web. Keramati, Afshari-Mofrad, and Kamrani (2011) proved that increasing student technology readiness in Iranian high schools could improve their e-learning outcomes in an information technology (IT) course as well as their intentions to learn on the Web. Moreover, Kurt and Gurcan (2010) pointed out that if the level of students' computer anxiety decreased, their intention to take web-based instruction could be increased.

Hwang and Kuo (2011, p 296) further defined "web-based problem solving” as the learning activities that engage students in comprehending a series of questions related to a specific issue, and seeking, selecting, abstracting, and summarising information on the Web to answer the questions. Several studies have shown that conducting web-based problem-solving activities can not only effectively improve learning 
performance, but can also increase positive attitudes towards problem solving. For example, Brand-Gruwel, Wopereis, and Walraven (2009) proposed a model based on information problem-solving on the Internet for secondary school students. The results reveal that the proposed model could improve students' problem-solving skills and attitudes towards the course. Wijekumar (2005) applied problem-solving processes to web-based courses for elementary school students, and found that their achievement and attitudes were significantly improved. A study by Hwang and Kuo (2011) also showed that web-based problem-solving activities could improve elementary school students' competence in using keywords and extracting proper information. Raes et al. (2012) used multiple scaffoldings as an approach to enhance both the knowledge acquisition and metacognitive awareness of junior high school students in web-based problem-solving activities for science courses. It can be seen that fostering students' problem-solving competence in web-based learning environments has become an important and widely discussed issue (Kuo, Hwang, \& Lee, 2012). Most of the studies have mainly focused on students’ learning performance in web-based problem-solving activities, while few studies have been conducted to investigate the influential factors of students' web-based problem-solving ability, not to mention using high-level statistical methods (e.g., structural equation modelling) to investigate the issue.

Consequently, an investigation into this issue using a high-level statistical analysis approach would help researchers as well as educators identify the critical factors that affect students' web-based problem-solving ability, and hence propose effective tutoring strategies.

\section{Theoretical background and research model}

To investigate the factors that could affect students' web-based problem-solving competence, six factors (i.e., Internet self-efficacy, task-technology fit, computer anxiety, technology readiness, web information seeking, and intention) are identified and elucidated as the primary dimensions based on a review of the relevant research and theoretical background. Moreover, a causal relationship model is constructed as shown in Figure 1, which depicts the basic components of the research framework. This model presumes that Internet self-efficacy (IS), task-technology fit (TT), and technology readiness (TR) will directly and positively affect intention (IN) to adopt the proposed web-based problem-solving learning approach, while computer anxiety (CA) will directly and negatively affect students' intention to use the approach. Finally, the impact of the antecedent variable (intention) on the web-based problem-solving learning performance of students is positively hypothesised, and it is also hypothesised that web information seeking competence (WS) directly affects the web-based problem-solving learning performance of students. In the following subsections, the factors and hypotheses are addressed in detail.

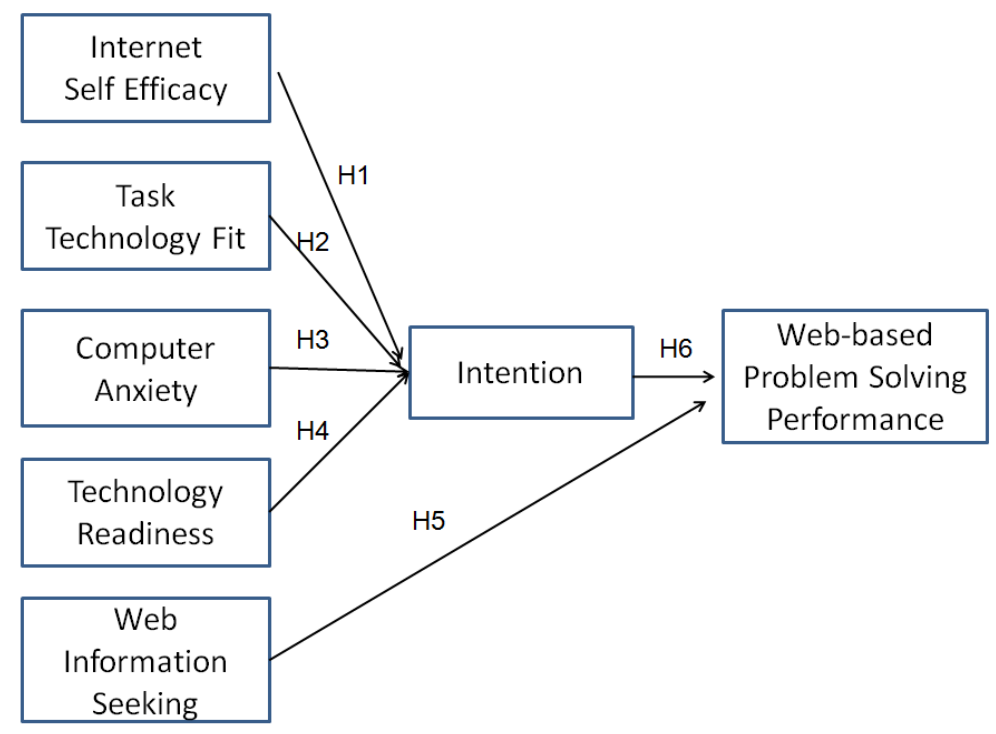

Figure 1. The hypothesised model for the study 


\section{Internet self-efficacy}

Internet self-efficacy (IS) refers to individuals' belief in their capability to use the Internet to organise information to produce given results; that is, IS represents personal judgment of one's ability to use the Internet (Eastin \& LaRose, 2000); for instance, when a person is asked to use the Internet to collect data or resources for a given task. Studies have concluded that IS has an impact on learning performance in online learning contexts. For example, the study by Joo, Bong, and Choi (2000) revealed that students' IS is related to their search outcomes on the Web, while Tsai and Tsai (2003) concluded that IS can foster better information searching strategies and learning outcomes in Internet-based environments.

Researchers have examined the effect of IS as an external variable of the intention to use technology. For example, several studies have reported that IS is the antecedent variable which positively influences individual behaviours of computer use (Compeau \& Higgins, 1995), surfing the Internet (Hsu \& Chiu, 2004) and search engine use (Liaw, Chang, Hung, \& Huang, 2006). Moreover, Liang, Wu, and Tsai (2011) found that IS could accurately predict nurses' actual behaviour or intention to take part in web-based continuing professional development (CPD). Thus, it is reasonable to assume that there is a relationship between IS and the intention to learn on the Web. Accordingly, the following hypothesis is proposed:

H1: Internet self-efficacy has a positive effect on the usage intention of adopting the web-based problem-solving learning approach.

\section{Task-technology fit}

Goodhue and Thompson (1995) proposed that an explanation of information system success needs to recognise both the task for which the technology is used and the fit between the task and the technology. Task-technology fit (TT) is defined as "the matching of the capabilities of the technology to the demands of the task, that is, the ability of IT to support a task" (Dwyer, 2007, 1022). TT is widely used as the explanation of technology utilisation, in contrast to the technology acceptance model (TAM), where the emphasis is on using beliefs of "perceived usefulness" and "perceived ease of use" to predict and explain users' acceptance of IT (Davis, 1989). As can be seen in Figure 2, the TT model has four key constructs: task requirements, technology functionality, which together affect the third construct, task-technology fit, which in turn affects the outcome variable, either performance or utilisation (Dishaw \& Strong, 1999).

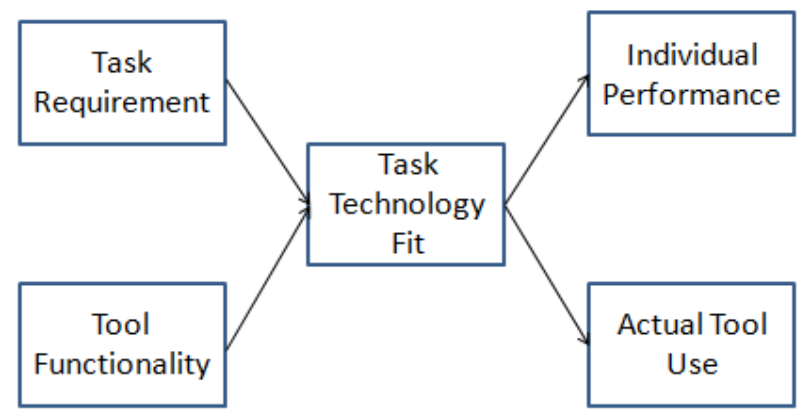

Figure 2. The task-technology fit model (Goodhue \& Thompson, 1995; p.220 )

The positive relationship between TT and actual system use has been confirmed in numerous studies (Dishaw \& Strong, 1999; Klopping \& McKinney, 2004). For example, the task-technology fit model proposed by Goodhue and Thompson's (1995, p.219) research presumes that the variances of "task characteristics," "technology characteristics," and users could directly or indirectly influence "utilisation" and "performance impacts." In addition, they also found that users' own cognition and beliefs could determine the strength of their behavioural intentions, thereafter affecting the final performance of their actual behaviour. Accordingly, the following hypothesis is proposed:

H2: Task-technology fit has a positive effect on the usage intention of adopting the web-based problem-solving learning approach. 


\section{Computer anxiety}

Computer anxiety (CA) refers to an individual's anxiety aroused in the process of using or facing a computer, and has significant influences on the individual's intention to use the computer. The main cause of this anxiety is the unfamiliarity with computers, which makes the users worried that they might appear clumsy in front of others or that their ignorance might cause damage to the computer (Chuo, Tsai, Lan, \& Tsai, 2011).

Doronina (1995) further summarised eight causes of CA, namely (1) individuals' fear of causing damage to the computer and worry that they may make mistakes, (2) a sense of uneasiness which results from the individual's feeling of ignorance or awkwardness when interacting with a computer, (3) a fear of computers which reflects the user's fear of technology or math, (4) individuals' concern that radiation might affect them and cause their health to deteriorate when they work in front of a computer, (5) individuals' fear of new or unfamiliar things leading to fear of computer technology, (6) individuals' worry that the computer will threaten or limit the development of their intelligence, (7) individuals' feeling that the time to use the computer is so insufficient that they will fail to take care of relevant matters within the pre-scheduled time, thus causing a state of psychological uneasiness, and (8) some individuals considering themselves inferior to the computer in intellectual development and being made to give up opportunities of independent thinking.

CA is associated with negative perceptions of computers, problems using them, and avoidance of the technology (Igbaria \& Iivari, 1995). Igbaria, Parasuraman, and Baroudi (1996) indicated that CA is negatively related to computer usage, perceived usefulness, perceived enjoyment, and social pressure. Moreover, several studies have shown that CA has direct effects on intentions to use technology (Van Raaij \& Schepers, 2008). Accordingly, the following hypothesis is proposed:

H3: Computer anxiety has a negative effect on the intention to adopt the web-based problem-solving learning approach.

\section{Technology readiness}

Technology readiness (TR) refers to people's propensity to embrace and use new technologies to accomplish goals in their home life and at work (Liljander, Gillberg, Gummerus, \& van Riel, 2006; Parasuraman, 2000). Based on the theory of diffusion of innovation (Rogers, 1962), Parasuraman's concept of TR focuses on the relationship between TR and intention to adopt technology-based products and services. The more ready one is to embrace new technology, the higher the possibility that one will intend to use technology-related products or services.

Research findings about the influences of these individual difference variables on technology acceptance are both limited and inconsistent (Dabholkar \& Bagozzi 2002). Fortunately, Parasuraman (2000) proposed the concept of TR, which can gauge both users' attitudes towards technology and other demographic attributes. In particular, TR incorporates people's feelings of optimism, innovativeness, discomfort, or insecurity about the use of technology in the determination of a person's readiness to use technology. Lai and Chong (2007) found that vocational high school students who have a strong level of TR would have strong intentions to use e-learning systems and positive attitudes towards e-learning. Lin, Shih, and Sher (2007) proposed a framework that integrates TR into the TAM, indicating that TR could directly affect learners' intention to use technology and indirectly affect learning performance. TR is a crucial factor that contributes to the success of any technology-enriched learning program. Thus, the following hypothesis is proposed:

H4: Technology readiness has a positive effect on the intention usage of adopting the web-based problem-solving learning approach. 


\section{Web information seeking}

Web information seeking (WS) is different from IS, in that it refers to information seeking as a process driven by humans' need for information so that they can interact with the Internet environment, emphasising communication and the needs, characteristics, and actions of information seekers (Marchionini, 1997). For instance, it refers to a person searching for the information he/she needs through the Internet when solving any problem. Studies have argued that WS facilitates the enhancement of students' academic performance through a series of information seeking activities on the Internet; that is, locating, comparing, and assessing the searched results from the Internet could enhance student learning performance (Hwang \& Kuo, 2011; Kuo, Hwang, Chen, \& Chen, 2012; Zhu, Chen, Chen, \& Chern, 2011). For example, knowledge acquisition can be achieved by either viewing or searching for information, and multiple results then call for the need to make comparisons or aggregations of the data and concepts. Viewing or searching in Internet communities of interest may expose students to different ways of learning or different methodologies; thus, the student's general learning capability is improved via socialisation (Marchionini, 2006). Zhu et al. (2011) indicated that the academic performance of 295 vocational high school students was affected by WS ability within the web-based learning activities. The learning, in turn, is reflected in the students' academic performance. Based on the above discussion, the following hypothesis is proposed:

H5: Web information seeking has a positive effect on students' problem-solving performance.

\section{Intention}

Intention (IN) refers to an individual's subjective likelihood of performing a specified behaviour, and is the major determinant of actual usage behaviour (Ajzen, 1985; Ajzen \& Fishbein, 1980).

Many studies have focused on the investigation of the relationship between learners' intention to use technology and their learning achievement, finding a positive effect existing between these two variables. For example, Watjatrakul (2011) found that university students' intention to use a mobile messaging service would directly affect their learning outcomes in a mobile learning model. Lau and Woods (2008) conducted an empirical study of learning object acceptance in a multimedia learning environment, and found that perceived usefulness positively affected behavioural intention to use multimedia; subsequently this intention directly affected the participants' learning effectiveness in the multimedia learning environment. Lim, Lee, and Nam (2007) found that the intention to use e-learning is one of the positive determinant variables affecting the academic effectiveness of students. Accordingly, the study assumes that the students' intention to adopt the web-based problem-solving learning approach will positively affect their learning effectiveness. Thus, the following hypothesis is proposed:

H6: Intention has a positive effect on students' web-based problem-solving performance.

\section{Research method}

\section{Experimental design}

Figure 3 shows the web-based problem-solving approach, which is a five-phase learning cycle adapted from Eisenberg and Berkowitz's (1996) big six method consisting, sequentially, of task definition, information seeking strategies, location and access, use of information, synthesis, and evaluation. The five phases of the web-based problem-solving approach are proposed and described in detail in the following sections. 


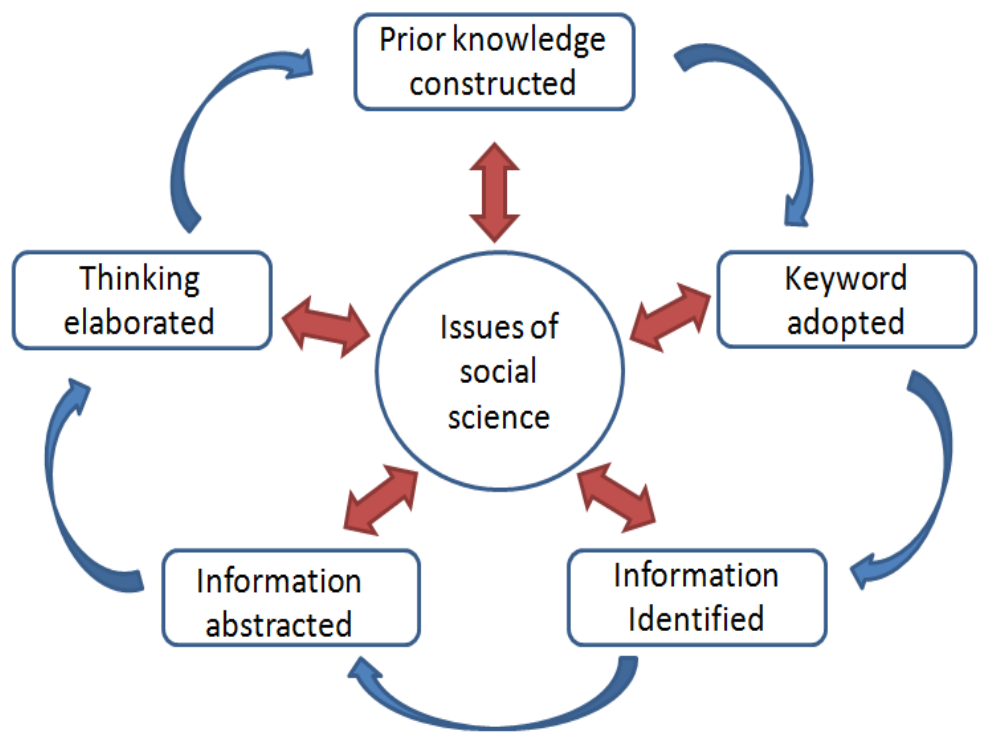

Figure 3. Learning cycle of the web-based problem-solving model

Prior knowledge construction

Based on the meaningful learning theory (Ausubel, 1962), in order for acquisition of new knowledge to take place and to be meaningful, prior knowledge needs to be activated by means of an introductory session. Thus, the first phase of the learning cycle is to introduce the prior knowledge concerning the issue that the students are going to inquire into on the Internet. For example, a conservation issue concerning white dolphins is proposed by the teacher who needs to introduce the background information about the white dolphin and why it is regarded as an endangered species.

\section{Keyword adopted}

An inquiry is a process during which individuals augment knowledge, resolve doubt, or solve a problem (Hodson \& Hodson, 1998). Acquiring knowledge from the Internet to solve problems has become a widely used learning approach in schools. Researchers have indicated that the competence of adopting appropriate keywords based on the problem is important in seeking information on the Internet; moreover, without proper guidance or training, children may have difficulty in determining the keywords (Bilal, 2002). Thus, the second phase of the learning cycle is to assist students in clarifying the problem, identifying the relevant concepts of the problem, and even linking or converting to other concepts.

\section{Information identified}

Finding the right information is an essential prerequisite of solving any problem. Even though the students may find the relevant Web pages, they cannot be certain of the correctness of the data. Thus, the third phase of the learning cycle is to guide the students to identify the relevant web pages, to look for accurate solutions, and to critique and compare the advantages and disadvantages of the proposed solutions before solving the problem.

\section{Information abstracted}

During the process of retrieving information from the web pages, it is an important ability for students to judge what pages need to be conserved and how to abstract useful information for solving the problem. Thus, the fourth phase of the learning cycle is to scaffold students to develop the information abstraction ability. During the scaffolding process, different detailed levels of step-by-step hints are given to the students to help them abstract information from the searched web pages based on their learning levels (Campione \& Brown, 1985); moreover, the scaffolding is decreased and eventually removed as the students' performance improves. 
Thinking elaborated

When the students have experienced a series of inquiry questions, more knowledge concerning a specific issue will have been constructed. They are therefore likely to have their own solutions based on a cognitive scheme. Thus, the fifth phase of the learning cycle is to ask the students to freely express their own ideas on the issue. This phase also offers an opportunity to other students for reflection on what they have done. Such a learning context is more likely to refine students' cognitive processing, which is consistent with Piaget's (1970) theory of cognitive development, and also with the theory of social constructivism (Vygotsky, 1978).

In this study, there are five sets of constructive questions for problem solving proposed by the researcher and instructors based on the current social issues addressed in the social studies course. These issues include nuclear power, water shortages, renewable energy, the greenhouse effect, and the garbage disposal problem.

\section{Experimental procedure and participants}

The participants for this study were 201 fifth- and sixth-graders from three elementary schools in southern Taiwan, aged 11-12 years. The experiment was conducted over a period of 5 weeks, and consisted of four stages, namely the pretest, learning system orientation, the experiment, and the post-test stage. The listed sequence and timing of the experimental procedure are shown in Figure 4 . The first stage, the pretest, was conducted for 40 minutes to measure the students' initial problem-solving ability, followed by an 80-minute orientation of the Meta-Analyzer learning system. When the students were familiar with the learning system, three sets of social science issues for web-based problem-solving activities were investigated over a period of six classes (240 minutes). Finally, the students' problem-solving ability was measured again, and they were asked to complete the multi-dimension affective questionnaires, totaling another 120 minutes.

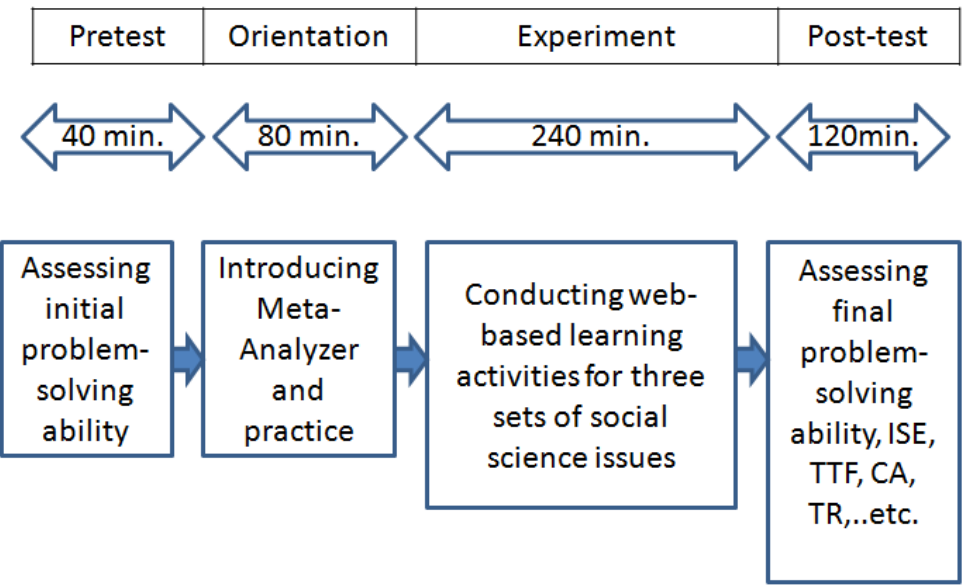

Figure 4. The experimental procedure of the study

\section{Tools}

Assessment of problem-solving ability

The assessment of problem-solving ability draws upon the test items proposed by Zhan and Wu (2007, p.58). The assessment consists of 10 items for evaluating the students' ability in terms of "awareness of problems," "identification of the nature of problems," "recognition of factors related to the problems," "identification of more information needed to solve the problems" and "determination of solutions." The perfect score for the assessment is 20 . The higher the score a student obtains, the better problem-solving ability the student presents. To ensure inter-rater reliability, four senior social studies teachers from four elementary schools were involved in the rating. Moreover, before the formal rating of the experiment, 32 non-experimental high-grade students participated in the test in an attempt to verify the correlation among the raters. Measured via Pearson correlation analysis, the inter-rater reliability of the pretest has a Cronbach's $\alpha$ value of 0.915 , showing high consistency between the ratings of the various teachers 
(Cohen, 1988).

\section{Research instruments for the structural equation modelling}

The causal relationship model in the study was measured with a questionnaire survey structured as follows: the first part consists of students' personal and academic data, while the second part includes seven dimensions for assessing the corresponding latent variables of the proposed model. For these seven dimensions there are 36 items in total, consisting of 5 for the Internet self-efficacy (IS) dimension developed based on the scale proposed by Eastin and LaRose (2000), 5 items for the task-technology fit (TT) dimension developed by Goodhue (1998), 5 items for the technology readiness (TR) dimension originating from the measure developed by Parasuraman (2000), 5 items for the computer anxiety (CA) dimension originating from the measure proposed by Lloyd and Gressard (1984), 5 items for the Web information seeking (WS) dimension originating from the measure developed by Choo, Detlor, and Turnbull (1998), 5 items for the intention (IN) dimension developed by Davis (1989), and 6 items for the problem-solving learning effectiveness (LE) dimension originating from the measure proposed by Gagne, Briggs, and Wager (1992). Descriptions and an example item for each construct are shown in Table 1.

Table 1

Description and example items for each construct

\begin{tabular}{|c|c|c|}
\hline $\begin{array}{c}\text { Construct } \\
\text { (abbrev.) }\end{array}$ & Description & Example items \\
\hline IS & $\begin{array}{l}\text { The degree to which individuals } \\
\text { judge their capabilities to use the } \\
\text { Internet in diverse learning } \\
\text { situations }\end{array}$ & $\begin{array}{l}\text { - I can search for information by using } \\
\text { keywords. } \\
\text { - I can surf a website by inputting its address. }\end{array}$ \\
\hline $\mathrm{TT}$ & $\begin{array}{l}\text { The matching of the IT capability to } \\
\text { the demands of the task }\end{array}$ & $\begin{array}{l}\text { The questions of Meta-Analyzer can guide } \\
\text { me to deeply understand the meaning of } \\
\text { social issues. }\end{array}$ \\
\hline CA & $\begin{array}{l}\text { An individual's anxiety aroused in } \\
\text { the process of using or facing a } \\
\text { computer }\end{array}$ & $\begin{array}{l}\text { - I will feel anxious when operating a } \\
\text { computer. } \\
\text { - I will be afraid of computer classes. }\end{array}$ \\
\hline TR & $\begin{array}{l}\text { People's tendency to embrace and } \\
\text { employ new technologies to achieve } \\
\text { goals in their home life and at work }\end{array}$ & $\begin{array}{l}\text { - I won't worry about information leakage } \\
\text { when transmitting messages on the Internet. } \\
\text { - I believe that information I get on the Web } \\
\text { is safe and correct as long as I keep } \\
\text { checking. }\end{array}$ \\
\hline WS & $\begin{array}{l}\text { The degree to which an individual } \\
\text { prefers to use the Internet to seek } \\
\text { information }\end{array}$ & $\begin{array}{l}\text { - I prefer to search for information I need } \\
\text { from the Internet. } \\
\text { - I am used to finding out information by } \\
\text { surfing the Internet when solving problems. }\end{array}$ \\
\hline IN & $\begin{array}{l}\text { The degree to which a learner } \\
\text { intends to adopt the proposed } \\
\text { learning context }\end{array}$ & $\begin{array}{l}\text { I would like to apply this kind of learning } \\
\text { mode to other subjects. } \\
\text { - I would like to recommend this kind of } \\
\text { learning mode to other class peers. }\end{array}$ \\
\hline LE & $\begin{array}{l}\text { An individual's web-based } \\
\text { problem-solving achievement and } \\
\text { learning achievement. }\end{array}$ & $\begin{array}{l}\text { - I believe this kind of learning mode could } \\
\text { enhance my keyword-adopting and } \\
\text { information recognising abilities. } \\
\text { - I believe this kind of learning mode could } \\
\text { raise my abilities in analysing and solving } \\
\text { problems. }\end{array}$ \\
\hline
\end{tabular}

These seven latent variables are measured via a 5-point Likert scale, ranging from 1 (strongly disagree) to 5 (strongly agree). Moreover, the items have been modified and adapted via an iterative personal interview process with two senior social studies teachers and one expert to verify the completeness, wording, and appropriateness of the instrument and to confirm its content validity. The Cronbach's $\alpha$ values of the seven dimensions are $0.87,0.81,0.82,0.90,0.84,0.85$ and 0.86 , respectively. 
The web-based learning environment

The web-based learning system, Meta-Analyzer, was developed by Hwang, Tsai, Tseng, Lin, and Tsai (2007) to assist teachers in tracing and analysing learners' information-searching behaviours for a series of questions related to some specific issues. It has been used in a number of studies as a tool to analyse the online information-searching behaviours of learners of various levels in a range of subject areas (Chiou, Hwang, \& Tseng, 2009; Hwang, Chen, Tsai, \& Tsai, 2011; Hwang, Tsai, Tsai, \& Tseng, 2008; Tseng, Hwang, Tsai, \& Tsai, 2009). As searching behaviours are not the main concern of this study, the data of the learners' web-based searching behaviours are not used or reported in this paper.

To efficiently conduct the problem-solving or searching process via Meta-Analyzer, four constructive inquiry-based questions are given to learners to search for information online for relevant learning units. Each question needs to be answered properly via the process of appropriate keyword adoption, information selection, summarisation, and integration, as shown in Figure 4. The searching behaviours of the students, including the keywords they use, the browsed pages, the time spent browsing the web pages and the user behaviours on the Web, are recorded on the server for cognitive quality analysis based on Bloom's (1956) cognitive levels, which are useful for educators to adjust their teaching strategies.

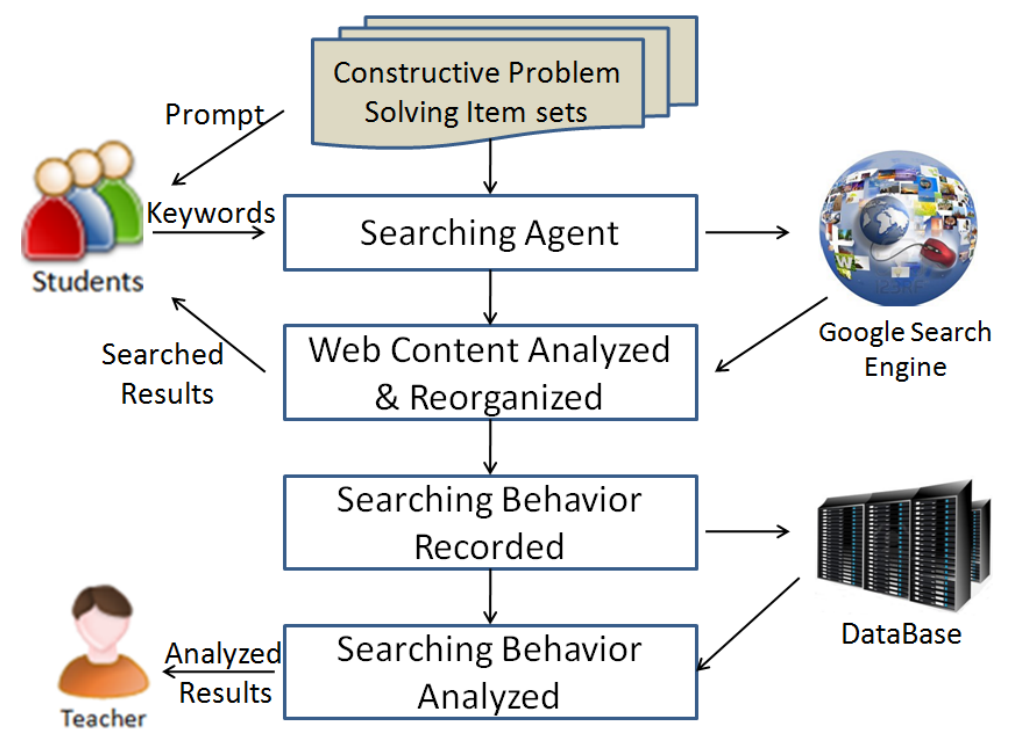

Figure 4. Framework of the web-based searching behaviour analysing system

The student interface consists of three operation areas: the question and answer area is located on the left side of the browser; the information searching area is located on the upper-right side; and the web pages found by the search engines are given on the lower-right side. To answer the questions, the students can input keywords to search for information, and then browse the web pages that might be relevant to the topic, as shown in Figure 5. 


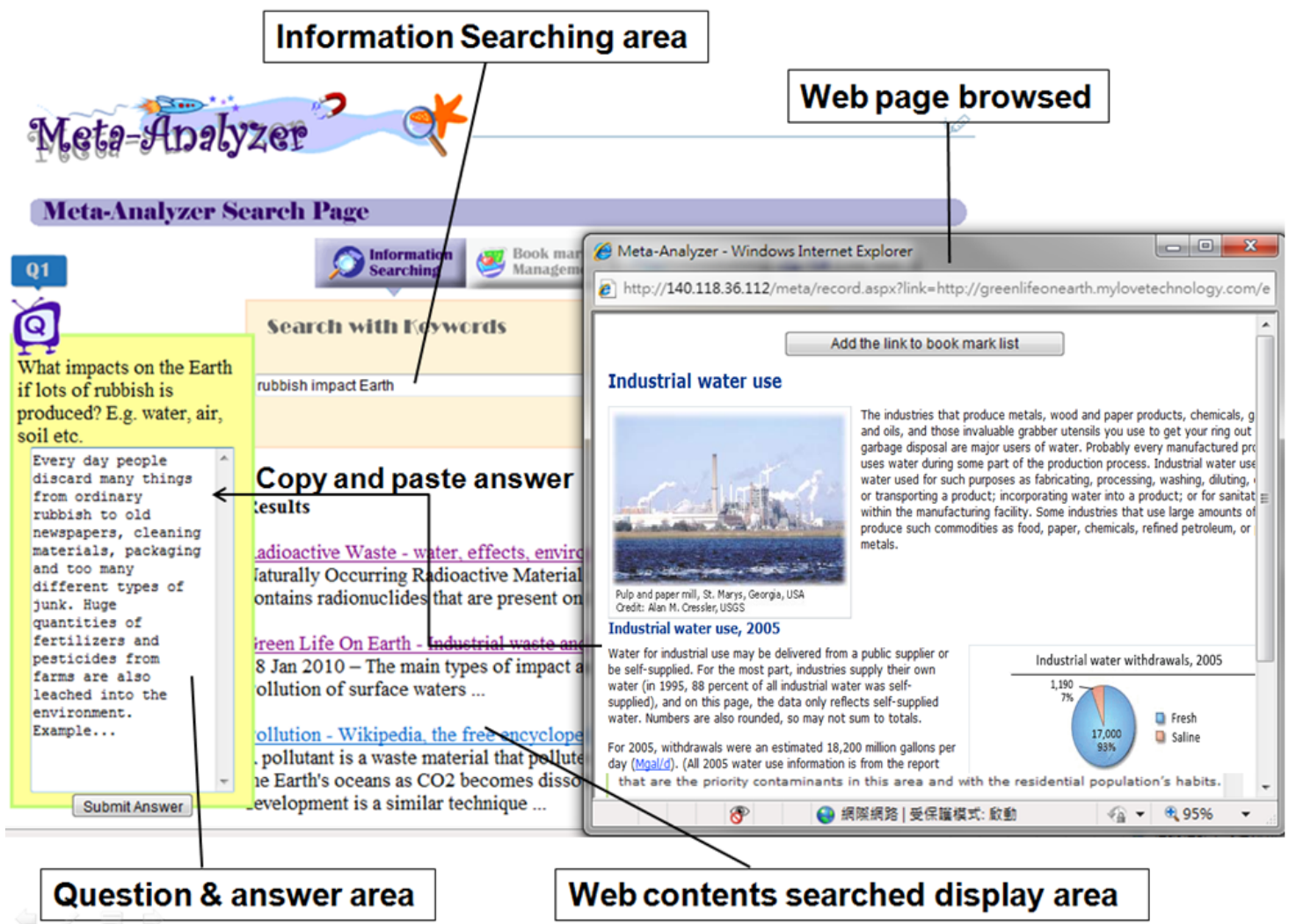

Figure 5. Student interface of Meta-Analyzer

\section{Results}

\section{Assessment of problem-solving ability}

Applying the problem-solving ability assessment developed by Zhan and Wu (2007), a paired samples $t$-test was employed to compare the test scores of the students before and after the experiment, as shown in Table 2. It was found that the students' post-test scores of problem-solving ability assessment significantly improved in comparison with their pretest scores $(t=12.27, p<.001)$. This result implies that the five-phase learning approach could be helpful to the students in terms of improving their problem-solving ability.

Table 2

Paired samples t-test for students' problem-solving ability

\begin{tabular}{llllc}
\hline & N & Mean & SD & $t$-value \\
\hline Pretest & 201 & 11.78 & 3.43 & $12.27^{* * *}$ \\
Post-test & 201 & 14.82 & 2.68 & \\
\hline
\end{tabular}

$$
p<.001
$$

\section{Measurement validation}

To ensure the quality of measuring potential factors that might affect the web-based problem-solving performance of the students, a statistical analysis was performed to evaluate convergent validity, such as the individual item reliability, construct reliability (CR), and average variance extracted (AVE) of the questionnaire by taking the indicators (i.e., the questionnaire items) as measures of latent variables (Fornell \& Larcker, 1981). The measurement model was evaluated by employing the partial least square (PLS) and the confirmatory factor analysis (CFA) based on three criteria suggested by Fornell and Larcker (1981), namely: 
(1) All indicator factor loadings should be significant and exceed 0.5.

(2) Composite reliabilities should exceed 0.7 .

(3) AVE by each construct should exceed the variance due to measurement error for the construct (i.e., AVE should exceed 0.5).

The Cronbach's $\alpha$ values, shown in Table 3, indicate that each construct exhibits strong internal reliability, as all the standard factor loading values in the CFA of the measurement model exceed 0.5 and are significant at $p=0.001$. In addition, the composite reliabilities of the constructs range from 0.84 to 0.92, and the AVE, ranging from 0.51 to 0.69 , is greater than the variance due to measurement error. Therefore, all three conditions for convergent validity are met, indicating good internal consistency (Fornell \& Larcker, 1981).

Table 3

Results of convergent validity of constructs

\begin{tabular}{ccccc}
\hline Constructs & $\begin{array}{c}\text { Composite } \\
\text { reliability }(>0.7)\end{array}$ & AVE $(>0.5)$ & $\begin{array}{c}\text { Factor loading } \\
(>0.5)\end{array}$ & $\begin{array}{c}\text { Measurement } \\
\text { error }\end{array}$ \\
\hline IS & 0.90 & 0.65 & 0.89 & 0.33 \\
TT & 0.84 & 0.51 & 0.82 & 0.48 \\
CA & 0.85 & 0.53 & 0.84 & 0.42 \\
TR & 0.92 & 0.69 & 0.92 & 0.31 \\
WS & 0.85 & 0.53 & 0.84 & 0.44 \\
IN & 0.87 & 0.56 & 0.87 & 0.41 \\
LE & 0.88 & 0.56 & 0.88 & 0.40 \\
\hline
\end{tabular}

Note: IS = Internet self-efficacy, TT = task-technology fit, CA = computer anxiety, TR = technology readiness, WS = web information seeking, $\mathrm{IN}=$ intention, $\mathrm{LE}=$ learning effectiveness.

Discriminant validity assesses the extent to which a concept and its indicators differ from another concept and its indicators (Bagozzi, Yi, \& Philipps, 1991). According to Fornell and Larcker (1981), the correlations between items in any two constructs should be lower than the square root of the average variance shared by items within a construct. As shown in Table 4, the square root of the variance shared between the construct and its items is greater than the correlations between the construct and any other construct in the model, satisfying Fornell and Larcker's (1981) criteria for discriminant validity. All diagonal values exceed the inter-construct correlations, and thus the results confirm that our instrument has satisfactory construct validity.

Table 4

Correlation matrix and discriminant validity of constructs

\begin{tabular}{cccccccccc}
\hline Constructs & Mean & SD & IN & LE & IS & TT & CA & TR & WS \\
\hline IN & 4.14 & .43 & $\mathbf{0 . 7 4 8}$ & & & & & & \\
LE & 4.26 & .63 & 0.193 & $\mathbf{0 . 7 4 8}$ & & & & & \\
IS & 3.86 & .51 & 0.111 & 0.134 & $\mathbf{0 . 8 0 6}$ & & & \\
TT & 4.03 & .40 & 0.148 & 0.185 & 0.098 & $\mathbf{0 . 7 1 4}$ & & & \\
CA & 2.09 & .52 & -0.120 & -0.152 & -0.090 & -0.115 & $\mathbf{0 . 7 2 8}$ & & \\
TR & 4.16 & .57 & 0.157 & 0.223 & 0.109 & 0.183 & -0.168 & $\mathbf{0 . 8 3 1}$ & $\mathbf{0 . 7 2 8}$ \\
WS & 4.06 & .41 & 0.114 & 0.191 & 0.086 & 0.128 & -0.108 & 0.201 & $\mathbf{0 . 7 2 8}$
\end{tabular}

Note: All correlations (off-diagonal elements) are significant at $p<0.05$. Diagonal elements (in italics and bold) are square roots of AVE. IN = intention, LE = learning effectiveness, IS = Internet self-efficacy, TT = task-technology fit, $\mathrm{CA}=$ computer anxiety, $\mathrm{TR}=$ technology readiness, $\mathrm{WS}=$ web information seeking.

\section{Structural model validation}

A model is said to fit the observed data to the extent that the covariance matrix it implies is equivalent to the observed covariance matrix (Hoyle, 1995). That is, the covariance matrix is a way of describing the relation between a collection of variables. A single covariance value describes the relationship between two variables. It is a tool for estimating the possible error in a numerical value and for predicting a 
numerical value. However, there are no recommended measures of model fit. In this study, seven common indices of fit with the values that are recommended in the literature (Hair, Anderson, Tatham, \& Black, 1998; Hu, Chau, Sheng, \& Tam, 1999) were employed to assess the model; that is, “ $\geqq .8$ ” for goodness-of-fit index (GFI) and adjusted goodness of fit index (AGFI), “ $\geqq .9$ ” for normed fit index (NFI), comparative fit index (CFI) and non-normed fit index (NNFI), “ $\leqq .05$ for root mean square residual (RMSR), and “.05-.08” for root mean square error of approximation (RMSEA). The commonly used measures of model fit, based on the results of an analysis of the structural model, are summarised in Table 5. As seen in Table 4, all goodness-of-fit statistics are in the acceptable ranges, with the exceptions of GFI (0.782) and AGFI (0.756), which are sensitive to sample size, but are close enough to the recommended value of 0.8 . On the whole, the various fit indices indicate that the research model has a good model fit.

Table 5

Assessment of structure model fit

\begin{tabular}{ccccccccc}
\hline Model fit indices & $\chi^{2} / \mathrm{df}$ & GFI & AGFI & NFI & CFI & NNFI & RMSR & RMSEA \\
\hline Recommended value & $\leqq 3$ & $\geqq .8$ & $\geqq .8$ & $\geqq .9$ & $\geqq .9$ & $\geqq .9$ & $\leqq .05$ & $.05-.08$ \\
Obtained & 1.82 & .782 & .756 & .957 & .980 & .978 & .019 & .061 \\
Supported & Yes & Close & Close & Yes & Yes & Yes & Yes & Yes \\
\hline
\end{tabular}

\section{Hypothesis testing}

Figure 5 shows the resulting path coefficients of the research model. Five out of six hypotheses were supported by the data. Among the external variables, technology readiness did not significantly influence intention $(\beta=-0.08, p>.05)$. However, Internet self-efficacy, task-technology fit and computer anxiety were significant influences on intention with $\beta$ values of $0.35(p<.001), 0.55(p<.001)$ and $-0.19(p<$ $.05)$ respectively. These four variables together explain $54 \%$ of the variance of intention $\left(\mathrm{R}^{2}=54 \%\right)$, and among these four variables, task-technology fit is the most influential factor for intention. Moreover, web information seeking and intention were significantly influential factors for problem-solving performance with $\beta$ values of 0.36 and 0.65 , respectively. Problem-solving performance in the study is jointly predicted by intention $(\beta=0.65, p<.001)$, and web information seeking $(\beta=0.36, p<.001)$ and these two variables together explain $56 \%$ of the variance in problem-solving performance $\left(\mathrm{R}^{2}=56 \%\right)$. Among these two variables, intention is the most influential factor for problem-solving performance. Table 6 summarises the results of the hypothesis test.

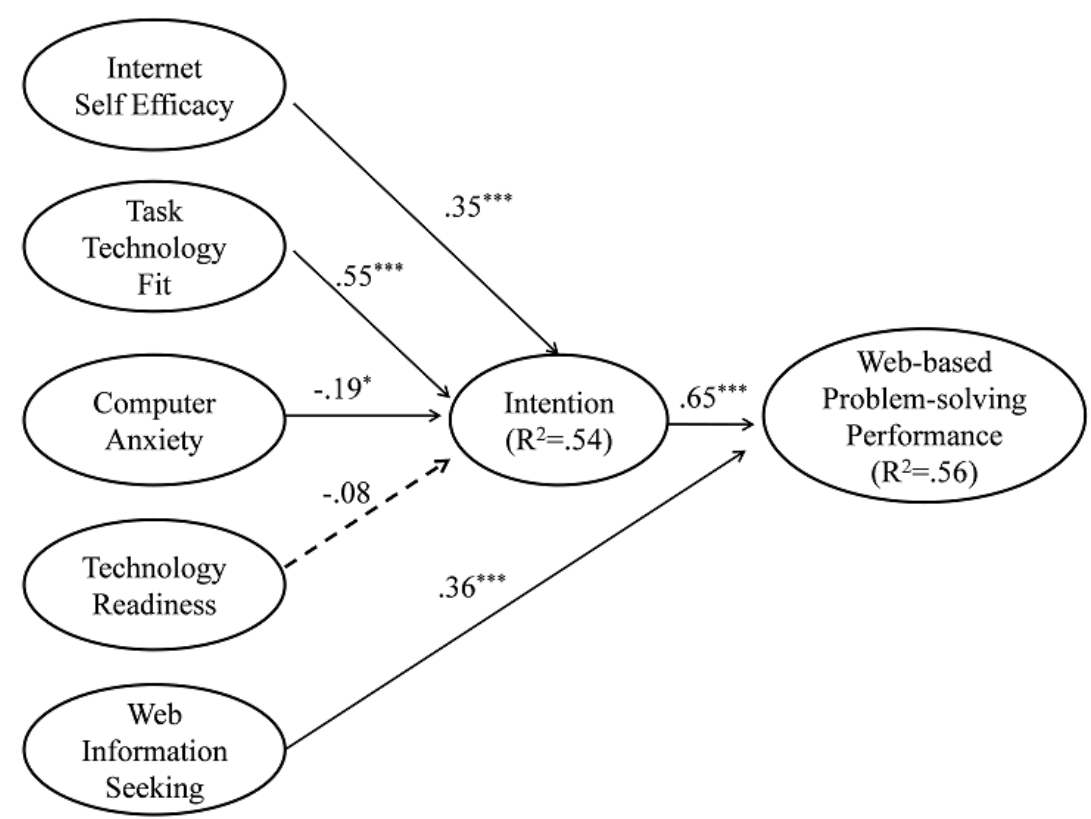

Figure 5. Standardised path coefficients of the research model 
Table 6

Inferred values of the research model

\begin{tabular}{ccccc}
\hline Hypotheses & From --> to & Standardised path $(\beta)$ & $t$-value & Supported \\
\hline H1 & IS -> IN & $0.35^{* * *}$ & 4.36 & Yes \\
H2 & TT -> IN & $0.55^{* * *}$ & 5.04 & Yes \\
H3 & CA -> IN & $-0.19^{*}$ & -2.165 & Yes \\
H4 & TR -> IN & -0.08 & -.95 & No \\
H5 & WS -> LE & $0.36^{* * *}$ & 5.14 & Yes \\
H6 & IN -> LE & $0.65^{* * *}$ & 7.77 & Yes \\
${ }^{*} p<.05,{ }^{* * *} p<.001$ & & &
\end{tabular}

\section{Standardised causal effects}

The present study mainly aims to identify the main determinants of elementary school students' problem-solving performance in web-based learning contexts.

Bollen (1989) mentioned that latent variables have three kinds of effect, namely direct effect, indirect effect and total effect, which are employed to explain the relationship among the latent variables. A coefficient linking one construct to another in the path model represents the direct effect of a determinant on an endogenous variable. An indirect effect reflects the impact a determinant has on a target variable through one or more other intervening variables in the model. A total effect on a given variable is the sum of the respective direct and indirect effects.

Internet self-efficacy with a total effect of 0.35 has a medium significant effect on intention. These four determinants account for approximately $54 \%$ of the variance in intention to adopt the proposed learning mode, with direct effects of $0.35,0.55,-0.19$ and -0.08 , respectively. This is largely due to the effects contributed by task-technology fit and Internet self-efficacy, thus stressing the importance of the relationship between these two variables. However, for technology readiness, this endogenous variable shows no significant effect on intention compared to the other three endogenous variables, as shown in Table 7.

Table 7

Summary of direct, indirect and total effects of the causal model

\begin{tabular}{|c|c|c|c|c|}
\hline \multirow{2}{*}{$\begin{array}{l}\text { Dependent latent } \\
\text { variables }\end{array}$} & \multirow[t]{2}{*}{ Independent latent variables } & \multicolumn{3}{|c|}{ Standardised estimates } \\
\hline & & Direct & Indirect & Total \\
\hline \multirow{5}{*}{$\begin{array}{l}\text { Intention } \\
\left(R^{2}=0.56\right)\end{array}$} & Internet self-efficacy & $0.35^{* * * *}$ & - & $0.35^{* * *}$ \\
\hline & Task technology fit & $0.55^{* * *}$ & - & $0.55^{* * *}$ \\
\hline & Computer anxiety & $-0.19^{*}$ & - & $-0.19^{*}$ \\
\hline & Technology readiness & -0.08 & - & -0.08 \\
\hline & Internet self-efficacy & - & $0.23^{* * *}$ & $0.23^{* * *}$ \\
\hline \multirow{5}{*}{$\begin{array}{c}\text { Web-based } \\
\text { problem-solving } \\
\text { performance } \\
\left(R^{2}=0.54\right)\end{array}$} & Task-technology fit & - & $0.36^{* * *}$ & $0.36^{* * *}$ \\
\hline & Computer anxiety & - & $-0.12^{*}$ & $-0.12^{*}$ \\
\hline & Technology readiness & - & -0.05 & -0.05 \\
\hline & Web information seeking & $0.36^{* * *}$ & - & $0.36^{* * *}$ \\
\hline & Intention & $0.65^{* * *}$ & - & $0.65^{* * *}$ \\
\hline
\end{tabular}

${ }^{*} p<.05,{ }^{* * *} p<.01,{ }^{* * *} p<.001$

\section{Discussion and conclusions}

Web-based learning environments have become one of the most prominent instructional delivery alternatives in schools today. This study proposes a five-phase learning approach to promote students' web-based problem-solving performance; moreover, a theoretical model based on the problem-solving theory for investigating the key determinants of students' performance in the learning context is proposed. The analysis results using structural equation modeling approach provide strong evidence for the 
theoretical validity of each construct of learning performance. The estimate of 0.54 for the intention construct $\left(\mathrm{R}^{2}=54 \%\right)$ for these paths provides good support for the hypothesised impact of Internet self-efficacy, task-technology fit and computer anxiety on the dependent variable, intention. In addition, the estimate of 0.56 for the web-based problem-solving performance construct $\left(R^{2}=56 \%\right)$ denotes that web-based problem-solving performance as perceived by learners is both directly and indirectly mediated by the intention construct. Therefore, as a whole, the model has strong explanatory power for student problem-solving performance within the proposed online learning context.

The significant path coefficients and the value of the $\mathrm{R}^{2}$ increase our confidence in the hypothesis testing results and provide support for the association with problem-solving performance in the web-based learning context. The results show that problem-solving performance is affected by interaction with cognitive and social environmental factors, which ensures that technology alone does not cause learning to occur. This corresponds to the perspective of the social cognitive theory, that is, human behaviours have reciprocal interactions between cognitive, behavioural and environmental influences (Bandura, 1986).

The empirical results of this study indicate that intention is the most significant determinant of student problem-solving performance in a web-based learning context. Internet self-efficacy, task-technology fit, and computer anxiety provide an indirect contribution to problem-solving performance via the above determinants; in contrast, web information seeking provides a direct contribution to problem-solving performance. Accordingly, when students become more confident and capable of learning within the proposed web-based learning context, and are more accustomed to the problem-solving context, they will likely anticipate more benefits from the use of the proposed learning system, and foster positive intention to use the learning system, such that, overall, the system will be more helpful to the problem-solving performance of the students. The contributions and implications of the study are presented in the following.

Task-technology fit is inferred to be the biggest determinant among the antecedent constructs of problem-solving performance. That is, intention is the strongest predictor of learners' problem-solving performance, followed by task-technology fit, web information seeking, and Internet self-efficacy predictors. The intention-learning achievement link has been validated in academic research (Lau \& Woods, 2008; Lim et al., 2007; Watjatrakul, 2011), and its revalidation in the web-based learning context further attests to the robustness of this association. Furthermore, intention may be the key factor in explaining the students' acceptance of the web-based learning model because it is the strongest predictor of web-based problem-solving performance (reaching 56\% of variance). Among the latent variables influencing intention, task-technology fit is identified in this study as the first determinant of intention. Task-technology fit is the same critical cognitive belief as perceived usefulness, which is consistent with previous studies (Goodhue, Klein, \& March, 2000; Vessey, 1991), implying that problem-solving activities can be conducted appropriately by means of web-based information searching systems such as Meta-Analyzer to guide students to answer constructive questions about real-life social issues, whereby students' fundamental problem-solving concepts can be effectively developed. This also implies that the better the technology meets the learning task characteristics, the more the learning design can improve students' learning performance and intention to use the technology. Moreover, task-technology fit is also identified as having the biggest indirect effect on problem-solving performance among the latent variables of Internet self-efficacy, task-technology fit, computer anxiety, and technology readiness.

Internet self-efficacy, followed by task-technology fit, is the second significant predictor $(\beta=0.35, p$ $<.001$ ) of the intention construct. This prediction shows that the given web-based learning activities required the students to adopt keywords, search for related information, and identify and abstract essential information for answering the questions. Such a web-based problem-solving activity also promoted the students' confidence and competency in using the Internet when solving problems. Thus, based on this result, it can be suggested that educators organise pre-class learning activities for the promotion of using the Interne. For example, how to adopt keywords based on questions, how to copy and paste relevant information from searched pages, how to organise and abstract essential information, can all be taught and practised. That would increase students' confidence and intention to participate in web-based learning activities. 
Similarly, web information seeking followed by intention is the second significant predictor $(\beta=0.36, p$ $<.001$ ) of web-based problem-solving performance. This construct differs from Internet self-efficacy in that it emphasises the degree of a learner's preference to use the Internet for seeking information. This prediction shows that the given web-based learning activities required the students to search for information to answer the questions. The students would get used to a series of web-based problem-solving activities and gain better learning performance. Thus, this implies that it can be suggested that educators manage more web-based learning classes for students so that the students' web-based problem-solving performance can be enhanced. Accordingly, their digital literacy can also be improved (Kuiper, Volman, \& Terwei, 2009; Savage et al., 2010).

On the other hand, technology readiness is the only insignificant predictor $(\beta=-0.08, p>.05)$ of the intention construct. This suggests that the students had a positive propensity to use the technology service, which is inconsistent with previous studies (Lai \& Chong, 2007; Lin et al., 2007). This could be due to the fact that the students were accustomed to the network environment in which they would trust the safety and convenience brought by the proposed web-based problem-solving model.

Although this study provides insights into what determines students' problem-solving performance in the proposed web-based learning model, it has several limitations representing chances for future research. First, further research may be needed to examine the effect of individual characteristics (e.g., gender) in the learning performance of web-based learning via multi-group analysis. In recent years, the importance of gender difference in the Internet self-efficacy domain has been emphasised. For example, Gefen and Straub (1997) first investigated gender differences in perceptions of usefulness and ease of use of e-mail, and intention to use it. Later, Venkatesh and Morris (2003) conducted a series of studies on the moderating effect of gender on various relationships between constructs in the TAM. Tsai, Liang, Hou, and Tsai (2012) found that there would be an effect from the interaction between different search contexts and gender on students' online searching strategies. Thus, gender difference can be considered in studies focusing on the investigation of what determinants produce learning differences between male and female learners. Second, the model was validated using sample data gathered from three elementary schools in Taiwan. The fact that the participants come from one country limits the generalisability of the results. Other samples from different countries and cultures should be collected to confirm and refine the findings of this study. Third, studies have indicated that students who adopt collaborative learning strategies could have better learning achievement than those who use individual learning strategies (Kuo, Hwang, Chen, et al., 2012; Lazakidou \& Retalis, 2010; Neo, 2003). Few studies have investigated what factors could affect student performance in group activities. Thus, future research could investigate the factors affecting individual students’ web-based learning performance in a collaborative learning context.

\section{Acknowledgements}

This study is supported in part by the National Science Council and the Ministry of Education under contract numbers of NSC 101-2511-S-011 -005 -MY3, NSC 102-2511-S-011 -007 -MY3 and U19604.

\section{References}

Ausubel, D. P. (1962). A subsumption theory of meaningful learning and retention. Journal of General Psychology, 66, 312-224. doi:10.1080/00221309.1962.9711837

Ajzen, I. (1985). From intentions to action: A theory of planned behaviour. In J. Kuhl \& J. Beckmann (Eds.), Action control (pp. 11-39). Berlin: Springer. doi:10.1007/978-3-642-69746-3_2

Ajzen, I., \& Fishbein, M. (1980). Understanding attitudes and predicting social behavior. Englewood Cliffs, NJ: Prentice-Hall.

Ates, S., \& Cataloglu, E. (2007). The effects of students’ cognitive styles on conceptual understandings and problem solving skills in introductory mechanics. Research in Science \& Technological Education, 25(2), 167-78. doi:10.1080/02635140701250618

Bagozzi, R. P., Yi, Y., \& Philips, L. W. (1991). Assessing construct validity in organizational research. Administrative Science Quarterly, 36, 421-458. doi:10.2307/2393203 
Bandura, A. (1986). Social foundations of thought and action: A social cognitive theory. Englewood Cliffs, NJ: Prentice-Hall.

Bilal, D. (2001). Children's use of the Yahooligans! Web search engine: II. Cognitive and physical behaviors on research tasks. Journal of the American Society for Information Science and Technology, 52(2), 118-136. doi:10.1002/1097-4571

Bilal, D. (2002). Children's use of the Yahooligans! Web search engine. III. Cognitive and physical behaviors on fully self-generated search tasks. Journal of the American Society for Information Science and Technology, 53(13), 1170-1183. doi:10.1002/asi.10145

Bloom, B. S. (Ed.). (1956). Taxonomy of educational objectives. London: Longman.

Bollen, K. A. (1989). Structural equation modeling with latent variables. New York, NY: John Wiley.

Brand-Gruwel, S., Wopereis, I., \& Walraven, A. (2009). A descriptive model of information problem solving while using Internet. Computers \& Education, 53, 1207-1217. doi:10.1016/j.compedu.2009.06.004

Bransford, J., \& Stein, B. (1984). The IDEAL problem solver. New York, NY: W. H. Freeman.

Campione, J. C., \& Brown, A. L. (1985). Dynamic assessment: One approach and some initial data (Technical Report, No. 361). Washington, DC: Nation Institute of Child Health and Human Development. Retrieved from ERIC database. (ED269735)

Chang, C. Y., Barufald, J. P., Lin, M. C., \& Chen, Y. C. (2007). Assessing tenth-grade students’ problem solving ability online in the area of Earth sciences. Computers in Human Behavior, 23(4), 1971-1981. doi:10.1016/j.chb.2006.02.014

Chiou, C. K., Hwang, G. J., \& Tseng, J. C. R. (2009). An auto-scoring mechanism for evaluating problem-solving ability in a web-based learning environment. Computers \& Education, 53, 261-272. doi:10.1016/j.compedu.2009.02.006

Choo, C. W., Detlor, B., \& Turnbull, D. (1998). A behavioral model of information seeking on the Web: preliminary results of a study of how managers and IT specialists use the Web. In Proceedings of the ASIS Annual Meeting (Vol. 35, pp. 290-302). Retrieved from ERIC database. (EJ575873)

Chuo, Y. H., Tsai, C. H., Lan, Y. L., \& Tsai, C. S. (2011). The effect of organizational support, self efficacy, and computer anxiety on the usage intention of e-learning system in hospital. African Journal of Business Management, 5(14), 5518-5523. doi:10.5897/AJBM11.725

Cohen, J. (1988). Statistical power analysis for the behavioral sciences (2nd ed.). Hillsdale, NJ: Erlbaum.

Compeau, D. R., \& Higgins, C. A. (1995). Computer self-efficacy: Development of a measure and initial test. MIS Quarterly, 19(2), 189-211. Retrieved from http://dl.acm.org/citation.cfm?id=210999

Crippen, K., \& Eari, B. L. (2007). The impact of web-based worked examples and self-explanation on performance, problem solving, and self-efficacy. Computers \& Education, 49(3), 809-821. doi:10.1016/j.compedu.2005.11.018

Dabholkar, P. A., \& Bagozzi, R. P. (2002). An attitudinal model of technology-based self-service: Moderating effects of consumer traits and situational factors. Journal of the Academy of Marketing Science, 30, 318-341. doi:10.1177/0092070302303001

Davis, F. D. (1989). Perceived usefulness, perceived ease of use, and user acceptance of information technology. MIS Quarterly, 13(3), 319-339. Retrieved from http://dl.acm.org/citation.cfm?id=2017067

Dishaw, M. T., \& Strong, D. M. (1999). Extending the technology acceptance model with task-technology fit constructs. Information and Management, 36(1), 9-21. doi:10.1016/S0378-7206(98)00101-3

Dogru, M. (2008). The application of problem solving method on science teacher trainees on the solution of the environmental problems. Journal of Environmental \& Science Education, 3(1), 9-18. Retrieved from http://www.ijese.com/V3_N1_Dogru.pdf

Doronina, O. V. (1995). Fear of computers. Russian Education and Society, 37(2), 10-28. doi:10.2753/RES1060-9393370210

Dwyer, C. (2007, August). Task technology fit, the social technological gap, and social networking sites. Proceedings of the thirteenth Americas Conference on Information Systems. Keystone, Colorado. USA. http://aisel.aisnet.org/amcis2007/374

Eastin, M. A., \& LaRose, R. L. (2000). Internet self-efficacy and the psychology of the digital divide. Journal of Computer Mediated Communication, 6(1). doi:10.1111/j.1083-6101.2000.tb00110

Eisenberg, M. B., \& Berkowitz, R. E. (1990). Information problem solving: The Big Six skills approach to library \& information skills instruction. Norwood, NJ: Ablex. 
Eisenberg, M. B., \& Berkowitz, R. E. (1996). Teaching information \& technology skills: The big 6 in elementary schools. Worthington, $\mathrm{OH}$ : Linworth.

Elmer-Dewitt, P. (1995, March 1). Welcome to cyberspace. Time, 145(2), 4-11.

Francis, A. A. (2008). Students' ability levels and effectiveness of problem-solving instructional strategy. Journal of Social Science, 17(1), 5-8. Retrieved from http://www.krepublishers.com/02-Journals/JSS/JSS-17-0-000-000-2008-Web/JSS-17-1-001-08-AbstText/JSS-17-1-005-08-619-Adesoji-F-A/JSS-17-1-005-08-619-Adesoji-F-A-Tt.pdf

Fornell, C., \& Larcker, D. F. (1981). Evaluating structural equation models with unobservable variables and measurement error. Journal of Marketing Research, 18, 39-50. https://faculty-gsb.stanford.edu/larcker/PDF/6\%20Unobservable\%20Variables.pdf

Gagne, R. M., Briggs, L., \& Wager, W. (1992). Principles of instructional design (4th ed.). Fort Worth, TX: HBJ College Publishers.

Gardner, H. (1993). Multiple intelligences: The theory in practice. New York, NY: Basic Books.

Gefen, D., \& Straub, D. W. (1997). Gender differences in the perception and use of e-mail: An extension to the technology acceptance model. MIS Quarterly, 21(4), 389. doi:10.2307/249720

Gerdprasert, S., Pruksacheva, T. Panijpan, B., \& Ruenwongsa, P. (2010). Development of a web-based learning medium on mechanism of labor for nursing students. Nurse Education Today, 30(5), 464-469. doi:10.1016/j.nedt.2009.10.007

Goodhue, D. L. (1998). Development and measurement validity of a task-technology fit instrument for user evaluations of information systems. Decision Sciences, 29(1), 105-139. doi:10.1111/j.1540-5915.1998.tb01346.x

Goodhue, D. L., Klein, B.D., \& March, S. T. (2000). User evaluations of IS as surrogates for objective performance. Information \& Management, 38(2) 87-101. doi:10.1016/S0378-7206(00)00057-4

Goodhue, D. L., \& Thompson, R. L. (1995). Task-technology fit and individual performance. MIS Quarterly, 19(2), 213-236.

Gui, M., \& Argentin, G. (2011). Digital skills of Internet natives: Different forms of digital literacy in a random sample of northern Italian high school students. New Media \& Society, 13(6), 963-980. doi:10.1177/1461444810389751

Hair, J., Jr., Anderson, R., Tatham, R., \& Black, W. (1998). Multivariate data analysis (5th ed.). Upper Saddle River, NJ: Prentice-Hall.

Hodson, D., \& Hodson, J. (1998). From constructivism to social constructivism: A Vygotskian perspective on teaching and learning science. School Science Review, 79(289), 33-41.

Hoyle, R. (1995). The structural equation modeling approach: Basic concepts and fundamental issues. In R. H. Hoyle (Ed.), Structural equation modeling: Concepts, issues, and applications (pp. 1-15). Thousand Oaks, CA: Sage. doi:10.1177/0047287513478503

Hsu, M. H., \& Chiu, C.M. (2004). Internet self-efficacy and electronic service acceptance. Decision Support Systems, 38(3), 369-381. doi:10.1016/j.dss.2003.08.001

Hu, P. J., Chau, P. Y. K., Sheng, O. R. L., \& Tam, K. Y. (1999). Examining the technology acceptance model using physician acceptance of telemedicine technology. Journal of Management Information Systems, 16(2), 91-112. Retrieved from http://www.jstor.org/discover/10.2307/40398433?sid=21106403544093\&uid=4\&uid=2

Hwang, G. J., Chen, C. Y., Tsai, P. S., \& Tsai, C. C. (2011). An expert system for improving web-based problem-solving ability of students. Expert Systems with Applications, 38(7), 8664-8672. doi:10.1016/j.compedu.2013.11.005

Hwang, G. J., Chiu, L. Y., \& Chen, C. H (2015). A contextual game-based learning approach to improving students' inquiry-based learning performance in social studies courses. Computers \& Education, 81, 13-25. doi:10.1016/j.compedu.2014.09.006

Hwang, G. J., Hung, P. H., Chen, N. S., \& Liu, G. Z. (2014). Mindtool-assisted in-field learning (MAIL): An advanced ubiquitous learning project in Taiwan. Educational Technology \& Society, 17(2), 4-16. doi:10.1080/10494820.2013.825810

Hwang, G.-J., \& Kuo, F.-R. (2011). An information-summarizing instruction strategy for improving web-based problem-solving abilities of students. Australasian Journal of Educational Technology, 27(2), 290-306. Retrieved from http://ascilite.org.au/ajet/submission/index.php/AJET/article/view/971

Hwang, G. J., Tsai, P. S., Tsai, C. C., \& Tseng, J. C. R. (2008). A novel approach for assisting teachers in analyzing student web-searching behaviors. Computers \& Education, 51(2), 926-938. doi:0.1016/j.compedu.2007.09.011 
Hwang, G. J., Tsai, P. S., Tseng, J. C. R., Lin, C. C., \& Tsai, C. C. (2007, September). Meta-Analyzer: A web-based environment for analyzing student information searching behaviors. Paper presented at the Second International Conference on Innovative Computing, Information and Control (ICICIC-07). doi:10.1109/ICICIC.2007.384

Igbaria, M., \& Iivari, J. (1995). The effects of self-efficacy on computer usage. Omega, 23, 587-605. doi:10.1016/0305-0483(95)00035-6

Igbaria, M., Parasuraman, S., \& Baroudi, J. J. (1996). A motivation model of microcomputer usage. Journal of Management Information Systems, 13(1), 127-143. Retrieved from http://dl.acm.org/citation.cfm?id=1195917

Jang, S. J. (2009). Exploration of secondary students' creativity by integrating web-based technology into an innovative science curriculum. Computers \& Education, 52(1), 247-255. doi:10.1016/j.compedu.2008.08.002

Joo, Y. J., Bong, M., \& Choi, H. J. (2000). Self-efficacy for self-regulated learning, academic self-efficacy, and Internet self-efficacy in Web-based instruction. Educational Technology Research and Development, 48, 5-17. doi:10.1007/BF02313398

Kantra, S. (2014, March 27). 11 Google Search tips everyone should know. Time. Retrieved from http://time.com/39291/11-google-search-tips-everyone-should-know/

Keramati, A., Afshari-Mofrad, M., \& Kamrani, A. (2011). The role of readiness factors in e-learning outcomes: An empirical study. Computers \& Education, 57(3), 1919-1929. doi:10.1016/j.compedu.2011.04.005

Klopping, I. M., \& McKinney E. M. (2004). Extending the technology acceptance model and the task-technology fit model to consumer e-commerce. Information Technology, Learning \& Performance Journal, 22(1), 35-48. http://citeseerx.ist.psu.edu/viewdoc/download?doi=10.1.1.121.3397\&rep=rep1\&type=pdf

Kuiper, E., Volman, M., \& Terwei, J. (2009). Developing web literacy in collaborative inquiry activities. Computers \& Education, 52(3), 668-680. doi:10.1016/j.compedu.2008.11.010

Kuo, F. R., Chen, N. S., \& Hwang, G. J. (2014). A creative thinking approach to enhancing the web-based problem solving performance of university students. Computers \& Education, 72, 220-230. doi:10.1016/j.compedu.2013.11.005

Kuo, F.-R., \& Hwang, G. J. (2014). A five-phase learning cycle approach to improving the web-based problem-solving performance of students. Educational Technology \& Society, 17(1), 169-184. http://www.ifets.info/journals/17_1/15.pdf

Kuo, F.-R., Hwang, G. J., Chen, S. C., \& Chen, S. Y. (2012). A cognitive apprenticeship approach to facilitating web-based problem solving. Educational Technology \& Society, 15(4), 319-331. http://www.ifets.info/journals/15_4/27.pdf

Kuo, F.-R., Hwang, G.-J., \& Lee, C.-C. (2012). A hybrid approach to promoting students’ web-based problem solving competence and learning attitude. Computers \& Education, 58(1), 351-364. doi:10.1016/j.compedu.2011.09.020

Kurt, A. A., \& Gurcan, A. (2010). The comparison of learning strategies, computer anxiety and success states of students taking web-based and face-to-face instruction in higher education. Procedia Social and Behavioral Sciences, 9, 1153-1157. Retrieved from http://www.cihaddemirli.com/download/89667031168.pdf

Lai, M. L., \& Chong, M. M. (2007). Professional students' technology readiness, prior computing experience and acceptance of an e-learning system. Malaysian Accounting Review, 6(1), 85-101. Retrieved from http://intansalwani.com/yahoo_site_admin/assets/docs/Paper5.108190355.pdf

Lau, S. H., \& Woods, P. C. (2008). An empirical study of learning object acceptance in multimedia learning environment. Communications of the IBIMA, 5(1), 1-6. Retrieved from http://www.ibimapublishing.com/journals/CIBIMA/volume5/v5n1.pdf

Lazakidou, G., \& Retalis, S. (2010). Using computer supported collaborative learning strategies for helping students acquire self-regulated problem-solving skills in mathematics. Computers \& Education, 54(1), 3-13. doi:10.1016/j.compedu.2009.02.020

Liang, J.-C., Wu, S.-H., \& Tsai, C.-C. (2011). Nurses’ Internet-self-efficacy and attitudes toward web-based continuing learning. Nurse Education Today, 31(8), 768-773. doi:10.1016/j.nedt.2010.11.021

Liaw, S. S., Chang, W. C., Hung, W. H., \& Huang, H. M. (2006). Attitudes toward search engines as a learning assisted tool: Approach of Liaw and Huang's research model. Computers in Human Behavior, 22(2), 177-190. doi:10.1016/j.chb.2004.09.003 
Liljander, V., Gillberg, F., Gummerus, J., \& van Riel, A. (2006). Technology readiness and the evaluation and adoption of self-service technologies. Journal of Retail and Consumer Service, 13(3), 177-191. doi:10.1016/j.jretconser.2005.08.004

Lim, H., Lee, S. G., \& Nam, K. (2007). Validating e-learning factors affecting training effectiveness. International Journal of Information Management, 27(1), 22-35. doi:10.1016/j.ijinfomgt.2006.08.002

Lin, C. H., Shih, H. Y., \& Sher, P. J. (2007). Integrating technology readiness into technology acceptance: The TRAM model. Psychology \& Marketing, 24(7), 641-657. doi:10.1002/mar.20177

Lo, H. C. (2009). Utilizing computer-mediated communication tools for problem-based learning. Educational Technology \& Society, 12(1), 205-213. Retrieved from http://ifets.info/journals/12_1/16.pdf

Loyd, B. H., \& Gressard, C. (1984). Reliability and factorial validity of computer attitude scales. Educational and Psychological Measurement, 44, 501-505. doi:10.1177/0013164484442033

Marchionini, G. (1997). Information seeking in electronic environments. New York, NY: Cambridge University Press.

Marchionini, G. (2006). Exploratory search: From finding to understanding. Communication of the ACM, 49(4), 41-47. doi:10.1145/1121949.1121979

Narciss, S., Proske, A., \& Koerndle, H. (2007). Promoting self-regulated learning in web-based learning environments. Computers in Human Behavior, 23, 1126-1144. doi:10.1016/j.chb.2006.10.006

Neo, M. (2003). Developing a collaborative learning environment using a web-based design. Journal of Computer Assisted Learning, 19(4), 462-473. doi:10.1046/j.0266-4909.2003.00050.x

Oloruntegbe, K. O., Ikpe, A., \& Kukuru, J. D. (2010). Factors in students’ ability to connect school science with community and real-world life. Educational Research and Reviews, 5(7), 372-379. Retrieved from http://www.academicjournals.org/article/article1379610221_Oloruntegbe\%20et\%20al.pdf

Parasuraman, A. (2000). Technology readiness index (TRI): A multiple item scale to measure readiness to embrace new technologies. Journal of Service Research, 2(4), 307-321. doi:10.1177/1094670514539730

Piaget, J. (1970). Science of education and the psychology of the child. New York, NY: Viking.

Pimta, S., Tayruakham, S., \& Nuangchalerm, P. (2009). Factors influencing mathematic problem-solving ability of sixth grade students. Journal of Social Sciences, 5(4), 381-385. doi:10.3844/jssp.2009.381.385

Polya, G. (1957). How to solve it. Garden City, NY: Doubleday.

Raes, A, Schellens, T., Wever, B. D., \& Vanderhoven, E. (2012). Scaffolding information problem solving in web-based collaborative inquiry learning. Computers \& Education, 59(1), 82-94. doi:10.1016/j.compedu.2011.11.010

Rogers, E. M. (1962). Diffusion of ilnnovations. Glencoe, IL: Free Press.

Savage, R. S., Erten, O., Abrami, P., Hipps, G., Comaskey, E., \& Lierop, D. (2010). ABRACADABRA in the hands of teachers: The effectiveness of a web-based literacy intervention in grade 1 language arts programs. Computers \& Education, 55(2), 911-922. doi:10.1016/j.compedu.2010.04.002

Sellwood, P. (1989). The role of problem solving in developing thinking skills. The Technology Teacher, 49(3), 3-10.

Tsai, M. J., Liang, J. C., Hou, H. T., \& Tsai, C. C. (2012). University students' online information searching strategies in different search contexts. Australasian Journal of Educational Technology, 28(5), 881-895. Retrieved from http://ascilite.org.au/ajet/submission/index.php/AJET/article/view/822

Tsai, C. W., \& Shen, P. D. (2009). Applying web-enabled self-regulated learning and problem-based learning with initiation to involve low-achieving students in learning. Computers in Human Behavior, 25, 1189-1194. doi:10.1016/j.chb.2009.05.013

Tsai, M. J., \& Tsai, C. C. (2003). Information searching strategies in web-based science learning: The role of Internet self-efficacy. Innovations in Education and Teaching International, 40(1), 43-50. doi:10.1080/1355800032000038822

Tseng, J. C. R., Hwang, G. J., Tsai, P. S., \& Tsai, C. C. (2009). Meta-analyzer: A web-based learning environment for analyzing student information searching behaviors. International Journal of Innovative Computing, Information and Control, 5(3), 567-579. doi:10.1109/ICICIC.2007.384

Van Raaij, E. M., \& Schepers, J. J. L. (2008). The acceptance and use of a virtual learning environment in China. Computers and Education, 50(3), 838-852. doi:10.1016/j. compedu.2006.09.001 
Venkatesh, V., \& Morris, M. (2003). User acceptance of information technology: Toward a unified view. MIS Quarterly, 27(3), 425-478. doi:10.2307/30036540

Vessey, I. (1991). Cognitive fit: A theory-based analysis of the graphs versus tables literature. Decision Sciences, 22, 219-240. doi:10.1111/j.1540-5915.1991.tb00344.x

Vygotsky, L. (1978). Interaction between learning and development. In Mind in Society. Cambridge, MA: Harvard University Press.

Wang, S. L., \& Wu, P. Y. (2008). The role of feedback and self-efficacy on we-based learning: The social cognitive perspective. Computers \& Education, 51(4), 1589-1598. doi:10.1016/j.compedu.2008.03.004

Watjatrakul, B. (2011). Determinants of students' intentions to use a mobile messaging service in educational institutions: A theoretical model. Proceedings of World Academy of Science, Engineering and Technology, 73, 1-6. Retrieved from http://internationalscienceindex.org/publication/8365

Wijekumar, K. (2005). Creating effective web-based learning environments: Relevant research and practice. Innovate, 1(5), 1-5. Retrieved from http://citeseerx.ist.psu.edu/viewdoc/summary?doi=10.1.1.186.3794

Zakaria, E., \& Yusoff, N. (2009). Attitudes and problem-solving skills in algebra among Malaysian matriculation college students. European Journal of Social Sciences, 8(2), 232-245. Retrieved from http://itle.okstate.edu/FD/online_teaching/OSU\%20Online/LE.pdf

Zhan, S. M., \& Wu, W. T. (2007). Guide to problem solving assessment. Taipei: Psychological Publishing.

Zheng, R. (2007). Cognitive functionality of multimedia in problem solving. In T. Kidd \& H. Song (Eds.), Handbook of research on instructional systems and technology (pp. 230-246). Hershey, PA: Information Science Reference/IGI Global Publishing. doi:10.4018/978-1-59904-865-9

Zhu, Y. Q., Chen, L. Y., Chen, H. G., \& Chern, C. C. (2011). How does Internet information seeking help academic performance? The moderating and mediating roles of academic self-efficacy. Computers \& Education, 57(4), 2476-2484. doi:10.1016/j.compedu.2011.07.006

Corresponding author: Gwo-Jen Hwang, gjhwang.academic@gmail.com

Australasian Journal of Educational Technology (C) 2015.

Please cite as: Kuo, F-R. \& Hwang, G-J. (2015). A structural equation model to analyse the antecedents to students’ web-based problem-solving performance. Australasian Journal of Educational Technology, 31(4), 400-420. 